\title{
Understanding School Library Education and Library User Education in Jordan
}

\author{
By Raid Jameel Sulieman*
}

This study aims at determining the concept of School Library Education and the reality of its educational employment in Jordanian school libraries. Furthermore, it defines the concept of education via Jordanian school libraries, affective planning, and the importance of coordination between the library, the classroom teacher and the curriculum to achieve library goals. This study employs a descriptive method, through describing school libraries concepts and library education determinants. The data sources used are: the Jordanian Ministry of Education and its official reports. The study's recommendations are: One weekly class, minimum, entitled "library education" or "library and scientific research". Curriculums coordinating topics covered in the classroom along with topics covered in library education. Repositioning E-learning resources and integrating and aligning coherent electronic library resources with topics covered in the classroom. Conducting workshops/ training sessions for librarians and teachers that allow them to uncover great potentials to bind an effective corporation between libraries with school elements.

Keywords: Jordan school libraries, Library education, School libraries, School library curriculum.

\section{Introduction}

School libraries play an active and leading role in the educational process, where it helps pupils' continue education effectively so they can learn by themselves. School libraries bear the slogan "Learn how to teach yourself and search for information" (Aljahran 2007).

Since school libraries identify within educational institutions, it means that there should be a form of coordination between libraries and all the other elements within the educational institutions such as teachers, pupils, the curricula, and the programs. This format was planned in an interactive manner so that it functions efficiently and effectively.

School libraries in Jordan are seeking to develop their services and activate their educational role through supporting the educational process since the beginning.

Therefore, it is essential to define these concepts such as school libraries from an educational perspective, determine the mechanism with which libraries are involved in the educational process, also, to define the current educational

\footnotetext{
* Associate Professor, Al-Hussein Bin Talal University, Jordan.
} 
role of school libraries in Jordan to identify the gaps, and to correct mistaken concepts in order to employ them effectively and achieve its goals fully, especially after the Ministry of Education had worked on the development of schools and the educational curricula in line with the technological developments, as well as taking into consideration the digital environment dominating most activities for pupils' today.

Within the limits of this study, an attempt to clarify the reality of the employment of school libraries in the educational process in Jordan and specifically in the curriculum service, without delving in any other issues related to libraries; such as their criteria, numbers and services. However, these topics might accidently come up in the discussion because it is of related interest.

This study will illustrate how to employ school libraries in the educational process pertaining to curricula design in Jordan, and will determine the necessary road map by which it is possible to achieve the goals.

\section{Aim of the Paper}

In their efforts to develop the educational process to conform to modern educational theories, the Ministry of Education in Jordan worked to change the methods of education and educational concepts to develop new curricula that include the computerization of many of its learning components, and the development of its learning system, where libraries form one of its most important elements. Therefore, there is a need to measure the development of school libraries coinciding with the Ministry of Education suggested developments, and how much did it affects the employment of libraries in the educational process.

This Study Tries to Examine

- What are the educational concepts of school libraries?

- How could library programs' and services be planned and developed into curricula for the pupils?

- What is the extent of school libraries employment in the educational process in Jordan?

- Did school libraries get a fair share from the development of the educational system in Jordan?

\section{Study Objectives}

- To define the concept and role of school libraries in the educational process.

- To clarify the proper planning to develop library programs services into curricula for the pupils.

- To clarify the coordination between library elements, educational 
curricula studies and teachers.

- To determine the situation of employing school libraries in the educational process in Jordan.

\section{Importance of the Study}

There is a misunderstanding of the School Library concept and its importance among different school leaderships in Jordan. They understand that the educational role of school libraries is to store information resources and books or for entertainment only. This concept diminishes the role of school libraries in the educational process.

Therefore it's necessary to clarify this misunderstanding as the Ministry of Education has developed the educational system through establishing the ELearning System in the school education process as well as in the program (Eduwave 2015).

It is very important to determine the current situation of school libraries in the educational process to identify strengths and weaknesses in the role that these libraries play.

Only a few studies have addressed this subject, especially in Jordan. The results of this study can clarify the educational process concepts and the importance of school libraries curricula development.

\section{Literature Review}

The topic of school libraries has gained the attention of many researchers, but most Jordanian studies focused on the standards of school libraries.

The study conducted by UNRWA (2011) aimed at transferring their experience and setting the strategies and application tools for the school libraries in order to use them for the educational process application in the electronic era, for the e-learning system (Modular Object- Oriented DynamicMoodle) application. A sample study was conducted which consisted of (18) teachers and school libraries to pupils' in the $8^{\text {th }}$ grade in South Amman. The library services were provided through a Digital online environment designated for the UNRWA schools. Through this environment, many apprentices and pupils were registered in electronic classes where the applied knowledge strategy had been implemented on them; for the purpose of improving the school libraries effectiveness and evaluating the impact on the pupils' academic achievement, and training the librarians on the acquired knowledge strategy. Through preparing the pupils guide for the usage of school libraries to employ school libraries and improve the reading skills in English (extensive learning).

The results show that the activation of the library through acquired knowledge strategy has an impact on improving the pupils learning for the long-term compared to the conventional ways of using school libraries. The 
study recommends the application of this project for all school subjects, grades and teachers.

Aljahran (2007) studied the recognition of public secondary schools status alongside the library services standard in the Directorate of Southern Shouneh in Jordan. The sample consisted of 219 pupils. The study showed a lack of library specialists, suitable furniture and adequate space for libraries, a small number of library education lessons, and the need to computerize the libraries.

Almomane (1998) conducted a survey study of the Jordanian school libraries status. He recommended the appointment of a fulltime librarian for every 300 pupils, and the construction of a building for libraries in schools when the library is housed in a classroom area. Furthermore, the schools should be provided library course training.

Tougan (1995) studied the cultural and educational role of school libraries, in the educational process. The study concluded that the library should provide a library lesson (library education) on a weekly basis; so that the library could perform its educational role and enhance the school curriculum and subject program. The study also showed that librarians should develop library educational programs and teach library education. He also suggested some criteria for school library services.

El-sheikh (1989) conducted a study, which aimed to investigate the reality of secondary school libraries in Jordan compared to the British standards. The study sample included all secondary school libraries in Jordan. The results showed that there is a weakness in the standards application compared to the British standards.

At the level of the Arab and international studies Lance's and Schwarz's study (2012) is among the most recent and influential studies on school libraries, their employment in the educational process and their impact on pupils' achievement. Lance's study investigates 500 school libraries to verify the relationship between the infrastructure of these libraries including the human capital, modern technology, and trained personnel and the pupils' capabilities in reading and writing. While the Pennsylvania system for test ratings was adopted by the study, the University of Mansfield analyzed the ratings obtained in 2010 and 2011. The study revealed that there is a relationship between the infrastructure of the library and the concept based on the library and the process of teaching about the duties of a library in the educational process and between pupil's achievements. The study reveals that there is a great correlation between the distinctiveness of the libraries' infrastructure and the pupils' academic achievement. The better infrastructure libraries have the higher the scores the pupils' have on reading and writing tests (Lance and Loertscher 2005).

Abbas (2011) explored the library training program in King's Academy School and its relationship with the information culture and library training programs. In his study, he showed the library training curriculum standards. The library developed a training program to continue a library curriculum; which meets the needs of the pupils in the four secondary classes and evaluates the pupils' library skills in three different levels. A set of criteria was 
developed under each level in order to measure pupils' skills; these are the Cultural Information level, the Self-learning level, and the Social Responsibility level. The study recommended the necessity to teach the information culture through the collaboration between the librarian and the teacher.

Al-Maneh (2007), examined the employment of school libraries in the initial stages of education to support the curriculum in Riyadh. The sample consisted of 40 primary schools for girls; the study revealed that there is a weakness in the employment of school libraries to support the school curriculum. This weakness in employing school libraries stems from the lack of teachers' and the librarians' knowledge of the concept of library education. The study revealed the need to employ the library in planning and teaching processes and to strengthen the collaboration between administrators, counselors, librarians, and teachers.

Alasmari's (2001) study aimed to find the extent of school libraries employment by the teachers of social subject at the secondary level. The study sample consisted of (50) teachers working in (24) schools. The study concluded that the teaching overload limits the employment of the library in the educational process; furthermore, there is no library courses program for teaching library education.

If we compare this study with previous studies in Jordanian libraries, we will find that school libraries have not been studied from an educational perspective. These studies focused only on standards, as in the Aljahran, Almomane, and El-sheikh studies. While Tougan studied the role of school libraries and their effect on reading development and never touched on the reality of employing school libraries in the educational process in Jordan. Therefore, this study will be complementary to the series of Jordanian school libraries studies.

By comparing this study with other studies, we may find a resemblance in the handling of school libraries and their role in supporting the learning process, as in the Abbas and Alasmari studies. But this study addresses the issue of library education in Jordan and employs them in the learning process specifically.

This study depends on the assessment of public school libraries based on the activities and reports documented in the ministry of education and not the views of pupils, teachers, and librarians. This study will be complementary to previews studies.

\section{Methodology}

The descriptive approach has been employed in this study, drawing on references and previous studies precise to the concepts of school libraries and library education where the concept of library education has been defined. Furthermore, the use of the Ministry of Education of Jordan, educational 
directorates, the reports of the Ministry and its figures and activities has been utilized to determine the reality of library education and information in Jordan.

\section{The Concept of School Libraries, its Importance and Objectives}

"Per capita supply of basic skills for the use of books, libraries and information centers; efficient use helps to obtain any information required by the situation, whether for education, or for entertainment, or job satisfaction" (AlShafi 1993: 252).

The school library is a "system created to make the information resources available to the school principal, teachers, and pupils'; so that the system enriches the educational program developed by the school to achieve the functions of the educational process" (AL-Shimi 1986: 21). The comprehensive approach that defines school libraries in the modern era includes comprehensive library and Learning Centers.

1. Comprehensive library is a term used because of the comprehensiveness information resources, taking in under the consideration of all age groups of pupils and the availability of all the elements, standards, activities and objectives available.

2. Learning Centers because it motivates the pupils to self and continuous learning (Shawabkeh 2011: 98).

From these definitions, we can determine the importance of school libraries as an effective educational tool that achieves the aims of education and increases its effectiveness. School libraries enable the educational process approach development and guide pupils toward self-development. Here is where the role of the teachers begins to change from indoctrination and lecturing in the classroom to participation, guidance, and development of scientific research for pupils.

The importance of School Library Education in the preparation of a welleducated pupil who is capable of dealing with information societies; this was the motto adopted by International Federation of Library Association (IFLA). The main objective of the IFLA conference in 1985 was highlighting the importance of School Library Education and its relationship to the information and school libraries (Almomani 1998: 41).

There are multiple conventions for library education, including education, as (Library Instruction), (Bibliographic Instruction), (Library User Education), and (Information User Education). School libraries in their modern concept changed the prevailing belief that the educational process rely on only school books. 


\section{Educational Goals of School Libraries and the Requirements to Achieve Them}

The Association of College and Research Libraries (ACRL) in the United States has issued a 1979 guide that included a model of various types of the libraries' goals ${ }^{1}$. IFLA outlined the main points for school library services and education, including: the integration with the school curricula, educational programs, activities, and goals identification. These goals according to AlMomani (1998:42) are:

- Creating a link between learning from the curriculum and learning from information resources in the library.

- Allowing the pupils to acquire the ability to deal with information and to develop their skills permanently.

- Providing the necessary information for teachers and pupils through the development of a library educational program at each school

The most important measures to achieve the goals of school libraries are achieved through studying the beneficiary community, i.e. the study of the pupils' characteristics to determine their needs according to their ages.

According to Jean Piaget's cognitive development theories, four classifications have been made that can identify appropriate sources of information, their interpretations and employment to the different age groups.

Depending on the stages of cognitive development by Piaget, we can suggest the suitable information resources for each age group as shown in the following Table 1.

It could be argued that adolescence is a phase of cognitively turning from concrete thinking to abstract and preferring learning experiences and interactions with their peers. Morally, they are inclined to idealism and care about the rights and feelings of others. Emotionally, their sexual instinct increases. Socially, they seek appreciation for their efforts (Al- Hadidi 2011: 77-95).

\footnotetext{
${ }^{1}$ Association of College and Research Libraries (1979) Bibliographic Instruction Handbook. Chicago: American Library Association.
} 
Table 1. Stages of Cognitive Development by Piaget

\begin{tabular}{|c|c|c|c|c|}
\hline Stage & $\begin{array}{c}\text { Age } \\
\text { Group }\end{array}$ & Characteristics & $\begin{array}{c}\text { Information } \\
\text { resources available } \\
\text { at libraries }\end{array}$ & Age \\
\hline Sensorimotor & $\begin{array}{l}\text { Birth - } \\
2\end{array}$ & $\begin{array}{l}\text { In this stage, infants } \\
\text { progressively construct } \\
\text { knowledge and their } \\
\text { understanding of the } \\
\text { world by coordinating } \\
\text { experiences (such as } \\
\text { vision and hearing) with } \\
\text { physical interactions } \\
\text { with objects (such as } \\
\text { grasping, sucking, and } \\
\text { stepping). }\end{array}$ & $\begin{array}{l}\text { Sources of } \\
\text { information that } \\
\text { develop their minds } \\
\text { basic cognitive } \\
\text { abilities and the } \\
\text { sources designed to } \\
\text { differentiate } \\
\text { between things such } \\
\text { as colors, sizes and } \\
\text { geometric shapes }\end{array}$ & $0-2$ \\
\hline \multirow[t]{3}{*}{ Preoperational } & \multirow[t]{3}{*}{$2-7$} & \multirow{3}{*}{$\begin{array}{l}\text { Uses language, and is } \\
\text { able to represent the } \\
\text { themes through the } \\
\text { shadows and words. Still } \\
\text { stationed around self. } \\
\text { Classifies topics based } \\
\text { on just one dimension, in } \\
\text { the later years of this } \\
\text { stage, begins using } \\
\text { numbers and developing } \\
\text { conservation concepts. }\end{array}$} & $\begin{array}{l}\text { Photos and } \\
\text { storyboards }\end{array}$ & $2-3.5$ \\
\hline & & & $\begin{array}{l}\text { Stories that include } \\
\text { expressive words } \\
\text { and images of } \\
\text { expressive, stories } \\
\text { that have a } \\
\text { relationship with } \\
\text { their surroundings, } \\
\text { such as stories about } \\
\text { the animals (cats, } \\
\text { dogs, etc.) and } \\
\text { simplified } \\
\text { audiovisual } \\
\text { materials. }\end{array}$ & $4-5$ \\
\hline & & & $\begin{array}{l}\text { Provision of } \\
\text { information sources } \\
\text { such as printed } \\
\text { books or periodicals } \\
\text { or dictionaries and } \\
\text { encyclopedia or } \\
\text { providing it } \\
\text { electronically, and } \\
\text { providing them with } \\
\text { the legendary } \\
\text { stories. }\end{array}$ & $6-7$ \\
\hline $\begin{array}{l}\text { Concrete } \\
\text { Operational }\end{array}$ & $7-12$ & $\begin{array}{c}\text { Capable of logical } \\
\text { thinking } \\
\text { Learn conservation } \\
\text { concepts in the following } \\
\text { order: numbers (6 years), } \\
\text { mass ( } 7 \text { years), weight ( } 9 \\
\text { years) able to classify } \\
\text { subjects and order them } \\
\text { in chains based on } \\
\text { dimensions } \\
\text { Understands relationship } \\
\text { vocabulary (a is longer } \\
\text { than b) }\end{array}$ & $\begin{array}{c}\text { Sources of } \\
\text { information that } \\
\text { embody the true } \\
\text { reality of events, } \\
\text { nonfictional stories } \\
\text { are introduced at the } \\
\text { age of ten. Children } \\
\text { begin to develop } \\
\text { taste for trips, } \\
\text { customs and } \\
\text { traditions. }\end{array}$ & $7-10$ \\
\hline
\end{tabular}




\begin{tabular}{|c|c|c|c|c|}
\hline & & & $\begin{array}{l}\text { Books that are } \\
\text { related to sexual } \\
\text { differences. Girls } \\
\text { become interested in } \\
\text { certain trends that } \\
\text { may differ from } \\
\text { males e.g. books } \\
\text { that have emotional } \\
\text { story lines and that } \\
\text { stem from the } \\
\text { communities. By the } \\
\text { age of 12, every } \\
\text { child develops their } \\
\text { own set of interests } \\
\text { and likes. }\end{array}$ & $11-12$ \\
\hline \multirow[t]{2}{*}{$\begin{array}{l}\text { Formal } \\
\text { Operational } \\
\text { Period }\end{array}$} & \multirow[t]{2}{*}{$12-18$} & \multirow[t]{2}{*}{$\begin{array}{l}\text { Thinks about abstracts } \\
\text { and follows logical } \\
\text { assumptions, and } \\
\text { explains the basis of } \\
\text { assumptions. Isolates the } \\
\text { problem elements and } \\
\text { handles all possible } \\
\text { solutions on a regular } \\
\text { basis, and becomes } \\
\text { interested in hypothetical } \\
\text { matters and ideological } \\
\text { problems. }\end{array}$} & $\begin{array}{l}\text { Interests of the child } \\
\text { become more } \\
\text { personalized and } \\
\text { males tend to focus } \\
\text { their attention to } \\
\text { machines and } \\
\text { inventions and } \\
\text { experimentation and } \\
\text { seem to not provide } \\
\text { information sources } \\
\text { that promote } \\
\text { scientific methods, } \\
\text { especially Applied } \\
\text { Science, orientations } \\
\text { and girls tend to be } \\
\text { interested in literary, } \\
\text { emotional and social } \\
\text { books where you } \\
\text { start the process of } \\
\text { adolescence when } \\
\text { the kids. }\end{array}$ & $12-15$ \\
\hline & & & $\begin{array}{c}\text { The student } \\
\text { becomes } \\
\text { independent in his } \\
\text { choices and } \\
\text { interests. Here we } \\
\text { must recognize that } \\
\text { the librarian on the } \\
\text { interests of each } \\
\text { child provides } \\
\text { advanced services, } \\
\text { such as current } \\
\text { awareness and } \\
\text { selective } \\
\text { dissemination of } \\
\text { information. }\end{array}$ & $16-18$ \\
\hline
\end{tabular}

Source: Al-tartouri 2007, Tougan 1995: 12. 


\section{The Relationship between Teachers, Curriculum and Librarians in Achieving Library Education Goals}

The coordination between the classroom teacher, and the librarian, and the subjects included in the curriculum, and the information resources in the library contains information of all linked vocabulary curriculum, which is very important in achieving the goals of library education.

The Librarian has several roles to employ libraries in the educational process. Librarians play the role of "a teacher librarian, information specialist, and co-learning Instructional partner" (Shawabkeh 2011: 107). In the light of the digital environment, we can add another role, a system librarian. Perhaps Figure 1 shows the relationship between the teacher and the librarian and the curriculum and sources of information.

Figure 1. The Relationship between the Teacher, the Curriculum and the Librarian and Information Resources in Achieving the Goals of Library Education

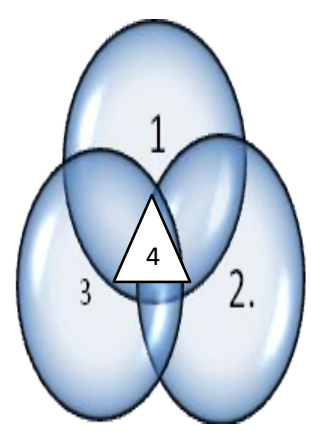

The numbers indicate:

Circle 1 is the Curriculum: Limited sources

Circle 2 is the Teacher: lecturing method (Indoctrination from the curriculum)

Circle 3 is the Library: expanding knowledge boarders (interaction and creativity)

Circle 4, Coordination between Curriculum and Teacher and library (Interaction area)

We limit the areas of cooperation between the teachers and the librarian in the following:

1. Requirement to facilitate library services for all students in school: through collaborative planning between teachers, and librarians, in connection with the selection of library collection.

2. Teachers are the owners of the first round in determining the form and content of books and information resources in the library.

3. It is important to review the library collections by teachers, before visiting the library by students to do their School duties, to make sure 
there are sufficient material and information recourses, to avoid students from experiencing failure in completing their duties.

4. Teachers and librarians are expected to work together in the library, to make sure that each student can find appropriate material for his interests, abilities and aptitudes.

5. It is important to give proper directions to the pupils to use the library, through encouraging them by the teachers and librarians.

A lot of problems face school education in Jordan at the current status, because of not understanding the libraries educational concept as follows:

1. The curriculum is limited to the cognitive framework of the book.

2. The momentum that is given in the curriculum leads to limiting the students' activity in expanding his/her knowledge of the circle outside the curriculum.

3. The belief that the educational process relies solely on the school book where often the teacher and information stand at the boundaries of what is written in the textbook and whether they consider the textbook only as teaching material.

4. users of school libraries are not given proper directions of how to use the library and they mostly depend on the librarians because they didn't educate the pupils how to use the libraries.

\section{Planning for Library Program Services as an Educational Concept in School Libraries}

Advanced planning before serving students in school libraries has many benefits, which are:

- Showing in advance all the necessary materials and resources needed to implement the library services program.

- Helping via coordination and integration between different services and activities.

- Achieving optimal utilization of the possibilities available.

- Preventing any problems before happening.

However, the planning for library program services as an educational concept depends on the library information resources, librarians and classroom teachers.

The classroom teachers and librarians play an important role in the planning process for any library service program, and when we say library program as an educational concept, that means the library educational curriculum. So the librarian should cooperate with the teacher to develop the library educational curriculum. And they should be familiar with the following: 
a. Good understanding of the library goals.

b. Familiarity with libraries work and planning.

c. Knowing the age stages of the children attending the library.

d. General school objectives knowledge.

e. An understanding of the educational curricula and subjects taught in the classroom along with the needed achievement by the teacher.

\section{Planning Steps for Library Program Services}

Firstly,

- Preparing a preliminary outline of the program (general and regular framework of the program) including:

- Pupils' categorization: total number of participating pupils', age stage, grade)

- Name of subject program: deepens on the subject that is taught in the class as history, math, and science.

- Time period for the program execution.

- Needed library materials: depends on the type of information to be given to the students, and types of experiences that must be acquired by the pupils.

Secondly, set the program goals which means:

- What are the expected results of experiences that must be acquired by the pupils

- What are the final results of the program?

- And determining the number of information resources required, and its category, this depends in the age stage of pupils' and grade.

Thirdly, choosing the program content and its execution and in this stage there should be coordination between librarians and classroom teachers and this depends on:

- The subject that is taught in the class.

- The work to be done by the pupils.

- The program contents must be: accurate and complete, consistent with the needs of pupils, raise pupil's interest; define the responsibilities of the pupils clearly.

Fourthly, prepare the necessary library information resources and materials:

- Making sure those self-education materials are available.

- Diversification of resources (e-resources, traditional resources, encyclopedias, biographies, audiovisuals resources, internet). 
Fifthly, preparing schedules that include time plans showing:

- The required implementation processes.

- Starting and finishing times.

Sixthly, evaluating and documenting the program.

Seventhly, organizing a table showing the library subjected educational activities (library education programs) such as the library educational curricula.

- Implementing a weekly library lecture and developing a library program for each subject taught during the semester (Tougan 1995: 23)

An example of library program services (course: Arabic language: a lesson Arar poetry).

1. The general framework of the program and the regulatory framework:

- Grade: 10th, the number of pupils 25 .

- Program duration: (3 meeting: one meeting each week).

- Title: library activity program (Arabic literature).

- (Enabling goal): writing a research on Arar's life and his poetry.

- Time to present the program: the 10 th, 11 th, and $12^{\text {th }}$ week.

- Resources: Encyclopedia of Jordan, biographies book: Arar's life and poetry, the complete works of Arar, Jordanian poetries in the era of the emirate, Wikipedia, documentary recorded on DVD for Arar's life and his poetry).

2. Equipment's needed: (library catalog to retrieve resources -display screen and DVD to watch a documentary about the poet Arar; a computer, a printer, papers and a room that can accommodate 25 pupils).

3. Setting and formulating the program's objectives:

- The objectives of the educational program: to expand the pupils' knowledge of national Jordanian writers and poets.

- To teach pupils how to write a research and prepare reports.

- To teach pupils how to use the information resources: Encyclopedia, biographies internet.

- Bibliography education: author, title, publisher, and year of publication.

- Students' skills: search and retrieval in the library catalog, Internet

4. The content of the program, technical steps to implement the program: 
- The teacher coordinates with the librarian to prepare for the actives.

- The teacher explains the topic that will be taught in the classroom to librarian; in this case the lesson is about Arar's poetry, The Librarian provides different information resources about Arar, (books or stories about him and his life, a photographed documentary of Arar, information about Arar from the Jordan Encyclopedia, especially on the Internet).

5. Determining the mechanism for delivering the program

Here the teacher divide the pupils into groups, the pupils retrieve the information resources by accessing the library catalog and the internet to find specific information about Arar, the pupils gather the information resources and collect the information about Arar, the librarian trains the pupils how to use the resources and how to document the references.

The teacher suggests to the pupils, how to organizing selective information in the research (UNRWA 2011:41-70).

6. The librarian and the teacher evaluate and edit the program and write a report, then the librarian documents and saves the program in the library for it to be reused in the coming years, and records the program in the library in the educational activities program calendar; by doing so, the school library can develop a curriculum for library education.

7. It is important to give proper directions to the pupils to use the library, through encouraging them by the teachers and librarians during the library activity.

This process is closer to the acquired knowledge strategy and enables the pupils to acquire Information literacy skills. It also motivates pupils to ask questions that they want to ask and obtain answers for. Then the pupils are trained on how to obtain the answers through information resources in the library.

When drafting library programs, the plan has to be realistic in its goals, being achievable and flexible so they can be adjusted. 
Figure 3. Library Curricula Program (Library Educational Program)

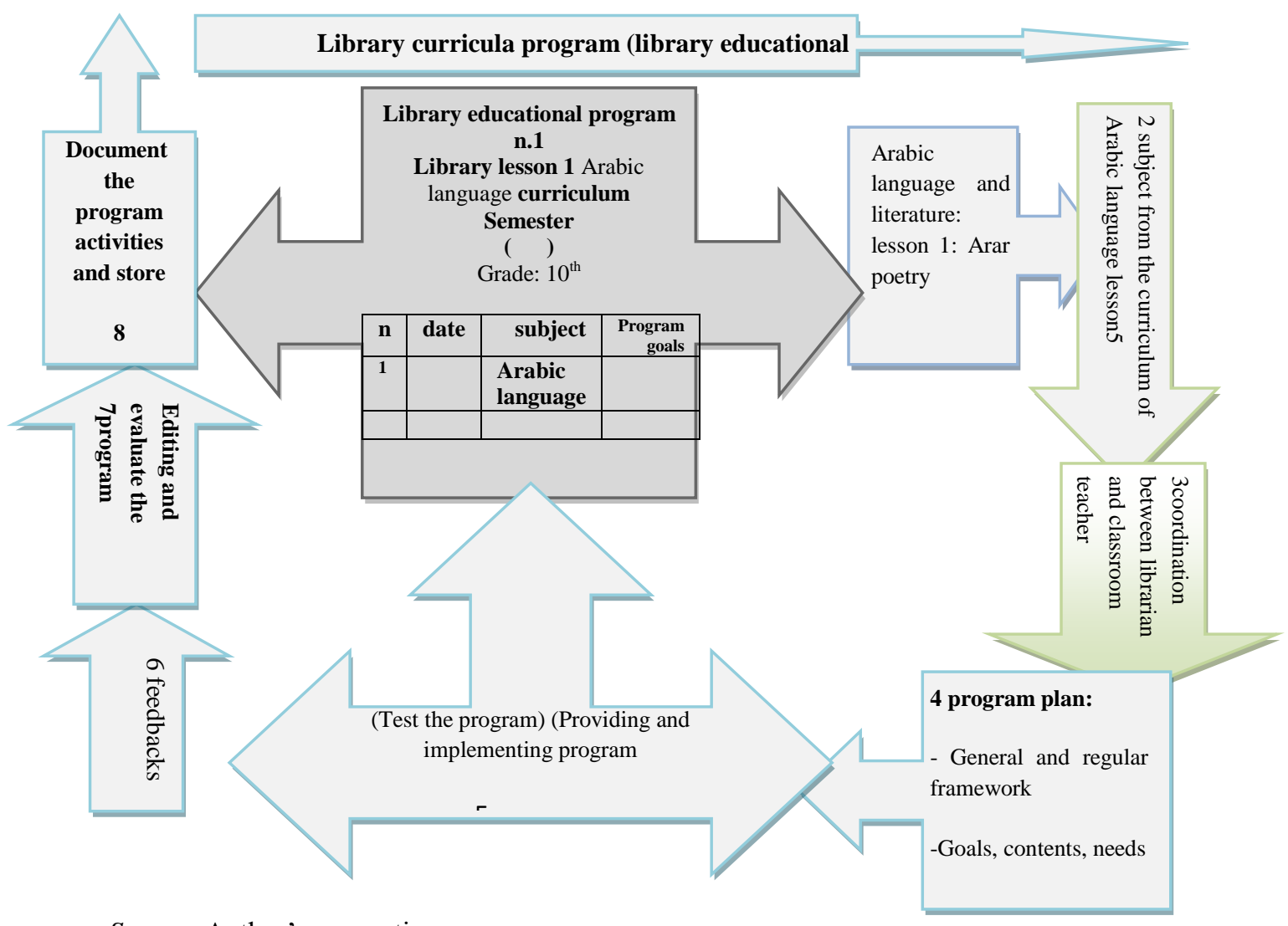

Source: Author's suggestion

There are no changes in the concepts of library education in the digital environment; the change was only in the way with which the services are provided. Along with e-learning and the computerization of the curriculum, new terminologies appeared such as "flexible learning", which enables pupils to become more engaged in the educational process, and thus enables them to control the pace of learning, according to their abilities, time and potential. They can use electronic curriculums from home and have access to the library, and use electronic information resources in the library, this process will help to self-continuous learning, which is the closest to Open learning via the library Education Open resources, Distance learning via the library Education Online access, and e-learning via the library Education e-resources or e-library. (Algrab 2008: 7).

Therefore many programs are running a combination of electronic curriculum and communicates with the teacher, student, library and information sources, the most important system which appeared in education and electronic -training is Moodle, a free and open resource software designed for school teachers so that they can create their material and upload it on the Internet with the possibility of direct and indirect communication with students directly and indirectly. This software includes special applications of training tasks for teachers, and applications for special examinations, other lessons, and other databases built by the teacher, according to what he/she sees fit. It allows 
them to assess the lesson or session in a questionnaire to gather information, and links to available information resources and libraries. The electronic resources here and electronic libraries are an important and integral part to the educational process of learning. This form of electronic libraries are an example of the employment of the library and its resources in a digital form as an important part of the e-learning system through the development of the resources of support information for the curriculum's digital form, if we want to implement the activity or the previous library program, one can go through the e-learning system, in coordination between the teacher and the librarian through transforming the traditional classroom environment to a virtual environment.

\section{The Reality of the Educational Role of School Libraries in Jordan}

Jordan began to pay attention to school libraries since the early days of school establishing in Jordan, where the Ministry of Education (MOE) in 1956 offered the late Mahmoud Al-Akhras a scholarship to The United Kingdom at the expense of UNESCO to study Librarianship and be trained to work in libraries in 1958. Mahmoud Al-Akhras is the pioneer of the librarianship development movement in Jordan, especially for the school libraries. The Department of Librarianship was established in the ministry to follow up with the development of libraries in schools; where this department was under the supervision of Al-Akharas's (Guendel 1995).

Al-Akhras has held a range of educational sessions over the years for those working in school libraries.

The first library in Jordan was Al- Salt Secondary School library; afterwards, the number of libraries increased to 23 (Elayyan 1999).

Hence, a new law -the law of school libraries that are under the supervision of the ministry- was introduced, (Education Act No. 16 of 1964).This law has defined the tasks assigned to the Department of School Libraries in accord with Article 117.

Among the instructions and decisions issued by the law of school libraries are the following:

- Allocating 30\% of student's enrollment fees for the library.

- Allocating one session per week for library activities for each class.

- Assigning a full-time librarian in high school libraries.

- Promoting reading through organizing competitions to encourage school students to attend libraries and to read, including the Distinguished Readers Competition under which special instructions had been issued for it (Guendel 1995: 76).

Establishing school libraries succeeded to reach up to 530 schools during the 70 s' of the past century. During the 1980s, the number of school libraries 
reached up to 1,750 , in which $40 \%$ of these libraries have had reserved halls dedicated to reading (Majali 2003: 175).

According to the study of Al Momani (1998: 18) the number of schools in the Kingdom in 1998, was in total $(3,050)$ schools, containing $(1,101)$ independent reading halls which constituted $(36.09 \%)$ the total number of schools that have exclusive libraries and reading halls. Whereas, (527) schools had rooms occupied as libraries by the rate of (17.27\%). In comparison between the affiliation of schools, it'd show that out of (788) governmental schools, (73.47\%) had available separate reading halls and (115) schools had rooms that are occupied as libraries, which equals to (14.6\%). As for governmental elementary schools, that were (1973), (338) had halls for reading exclusively, which results in (17.4\%). Private schools, schools of UNRWA and the armed forces schools number was (53) high schools where $(69.81 \%)$ of them had independent reading halls, (15) schools had rooms occupied as libraries resulting in $(28.30 \%)$, while there were (236) elementary schools, (147) of them had independent reading halls in total of (62.28\%) and (89) schools had rooms occupied as libraries, rated (37.71\%).

As for Jordanian universities, higher diploma programs were offered first, then bachelor's and master's programs in Librarianship were offered afterwards, such as the University of Jordan, The University of Balqa and the Zarqa Private University. At Al-Hussein Bin Talal University, since the academic year of 2006, school libraries and children's libraries courses were introduced (AHU-Arts 2007) for the students of kindergarten classroom teacher majors (AHU College of Education 2005).

Currently, in the (Ministry of Education 2013) there are $(6,355)$ schools in Jordan, including the $(1,544)$ kindergarten institutions, the number of elementary and secondary public schools is $(3,582)$ and $(2,773)$ private schools, which means that the number of elementary and secondary libraries is $(4,811)$ excluding kindergarten libraries.

These libraries were distributed according to the educational levels. $(3,303)$ school libraries for elementary stages and $(1,508)$ for secondary schools, these libraries serve $(1,726,831)$ students according to the statistics of school students numbers for the year 2012-2013.

The responsible body for school libraries is the Ministry of Education, represented by the Department of Libraries, which aims to develop school libraries; this section is under the administration of the Department of Curricula and Textbooks (Ministry of Education 2010). Some parts of its duties are:

- Examining the legislations related to the department and updating them for different purposes.

- Determining the needs of school libraries of books and furniture through the Directorates of Education to prepare for purchase lists in line with the allocations in the budget, according to financial regulations. 
- Preparing information for multiple uses in the field of libraries as references for librarians in schools and continuing to update the information regularly.

- Coordinating with the affiliated authorities to hold seminars and trainings for the school libraries' librarians.

- Providing the field with lists of books, references and periodicals which could be used to enrich school libraries.

- Participating in biddings related to the central and branch libraries, to buy furniture and planning its distribution to school districts through the administration of the supplies department.

- Developing the services of libraries and studying the reality of school libraries, both through field visits or the collection of statistical data about the need for adequate school libraries of both books and furniture.

- To monitor the mechanisms of periodicals and books acquisition and to provide them for the school libraries in accordance with the procedures followed in the system.

- Preparing the educational specifications for furniture and library materials. In addition to preparing the libraries' halls specifications in new buildings, that are built by the ministry, along with the General Directorate for Projects and Buildings.

There is also a Learning Resources Center within the unit of educational and technical affairs in each directorate of education in the governorates. Among its duties is to supervise school libraries and to keep on providing them with the necessary materials. Its duties also include following-up on designs and the production of pedagogical materials and employing them in the Directorate's schools to serve the educational process.

The Ministry of Education implemented a range of activities and procedures to develop school libraries, including:

- Organizing conferences, seminars, such as: the National Convention on school libraries in 1998 which had the most important recommendations advised in accordance to library education is the importance of implementing the library education session, setting up library skills and linking school libraries via a national information network; and every Monday of the second week of March was set to be Arab world day dedicated for school libraries where schools on that day should intensify their interest in the school library and raise awareness about their importance and effective role in supporting the curriculum (Symposium of the Present Situation of School Libraries in Jordan: 10).

The Ministry also introduced the "classroom books basket" within the recommendations of the National Conference for Educational Development, which resembled a classroom library to encourage and achieve emotional goals towards national belonging and patriotism and to increase the national education of students, hence, the topics of the information sources tackled the 
achievements of His Majesty the King Abdullah II, the ruling Hashemite family and the history of the Kingdom (Momani 1998: 65)

In 2011, a seminar on school libraries and their role in the educational process was held. The most important final recommendations were the necessity of including programs of general knowledge and training beneficiaries, curricular research skills within public and private schools and the allocation of some sessions in schools to apply these programs through the schools' curriculums (Symposium school libraries 2011: 11).

The Ministry of Education held many workshops for the school libraries, which include administrative aspects, as well as the computerization of libraries and training them on WINISIS software; in order to activate the role of school libraries in the educational process and develop the capacities of librarians to do management work in school libraries. Some school libraries organized promising initiatives heading towards activating the school libraries role in the educational process, but these attempts and activities remain individualistic (Ministry of Education 2015).

In addition, The Association of Jordan Libraries played a major role in the development of school libraries through conferences, seminars and holding qualifying courses for librarians of school libraries. The Association also provides suggestions for the Ministry of Education that aims to work on the development of school libraries and their role in education. Moreover, in the second conference of Jordanian Libraries in 1991, organized by the Association Jordanian Libraries, the most important recommendations related to hiring libraries in the educational process were the following:

- Allocating sufficient time (a session or more) per week for students to utilize libraries; in addition to opening schools outside working hours.

- Innovating school skills curriculum (library skills included) and rehearsing for each stage of the various stages of education (Second Conference Jordanians Librarians 1992).

In Jordan, there are many issues that limit the educational role of libraries, where there is no systematic studied achievement of libraries, and the common belief remains that the educational pedagogical process relies solely on the textbook, where there is neither in the public nor private framework for all in curricula or textbooks a course for library education (Ministry of Education Administration 2015).

The Ministry of Education in Jordan took good steps towards the development of libraries to activate its educational role to serve the educational process; however, it didn't employ libraries well to service the curriculum.

Recently, the Ministry computerized the curriculum and linked it to databases to access electronic sources of information, through the creation of the e-learning system (Eduwave) that was employed in the educational process.

The ministry did not provide within the e-learning system an electronic library or guided schools that there will be advanced school library services for libraries along with the availability of the electronic curriculum. 
The ministry implemented a survey in 2012 in order to identify the extent of readiness for the use of communication and information technology in all schools in the Kingdom, and to develop plans, strategies and programs that support the educational development of the knowledge-based economy, to create a national database to be used in schools.

The objectives of the surveys lacked indicators related to libraries or librarianship education, including its findings and recommendations (Ministry of Education 2012).

The surveys proposed:

- The need to activate the role of the Ministry of Education's website (Eduwave).

- The need to provide additional computer labs in schools to operate on the computerized curriculum.

- To activate information technology and communication usage in education.

- To conduct specialized surveys to examine the views of students on the usage of information technology and the extent and areas of its use.

- Designing a special curriculum for library education.

Based on previous surveys, it is noticeable that the ministry's faith is weak when it comes to the importance of librarianship education and school libraries and their role in supporting the educational process.

The e-learning system (Eduwave) would be incomplete if the Ministry did not reconsider examining its policies towards school libraries and their role in education to suit the present digital environment and what has been accomplished in computing the curriculum; building an educational database allowing students to access it and access information and educational programs, including for example, linking libraries and computerizing them so they would perform the maximum of their educational role.

It is also noticeable that among the duties of the library department in the ministry there is not the responsibility of the employment of the libraries in the educational process, in spite of the attempts of the ministry, by establishing libraries and mobile computer labs.

\section{Results}

School libraries in Jordan suffer from many problems that stand in the way of libraries in achieving their goals; one of the most important issues that stops school libraries from achieving their objectives is not having a specialized curriculum, official activities for library skills or programs like other curriculums, and that there is no specialized course dedicated to library education, and that is the result. 
Despite all the national and regional conferences, seminars and workshops which have been held in Jordan by the ministry and other institutions concerned with school libraries, such as the Library Association, which concluded recommendations urging the need to systematize library education and highlight the importance of activating the role of libraries in education, these recommendations were not taken into consideration and the Ministry of Education has focused instead on the formal aspect of school libraries. Although the Ministry of Education has developed the entire educational system and curricula, school libraries did not have a sufficient portion of the curriculum and the educational system (Eduwave 2015).

\section{Conclusion}

Accrediting an official curriculum for school students, where it should be aligned with the different curriculums' vocabulary including matching their topics, and there should be at least one session per week entitled library education or libraries and scientific research; moreover, there is an urgent need to reassess the e-learning system (Eduwave 2015) to allocate an inclusive electronic library, consistent with the vocabulary and curriculum topics, to represent a safe electronic haven able to assist students to complete their homework and broaden their perspectives out of the narrow curriculum into spacious and varied knowledge. With the need to conduct workshops and training sessions attended by school librarians and teachers to clarify the mechanism of how to employ libraries in the educational process as indicated above in the theoretical aspect.

\section{References}

Abbas Z (2011) Information Literacy and Library Curriculum at HRH Sheikh Mohammed bin Rashed AL Maktoum Library King's Academy. Risalat AlMaktaba: $15-39$.

Al Grab IM (2008) Electronic Learning, Introduction to Nontraditional Learning, 7. Cairo: Arab Administrative Al Hadidi M (2011) Communication Skills with the Secondary School Students. Risalat Al-Maktaba 46(2): 77-95.

Alasmari N (2011) The degree of hiring school library by teachers of social studies at the secondary level in serving the curriculum at the governorate of Mahayil, 179-179. Retrieved from http://b7oth.com/?p=1336.

Aljahran H 2(007) The Situation of Secondary School Libraries in the District of Southern Shouneh. Risalat Al-Maktaba [Library Message] 42(2): 129-151.

Al Majali SM (2003) Education and Teaching in Two Stages Before the Educational Development and Beyond, 175.Amman: Ministry of Education.

Al Momani G, Al Soufi A, Abu Juma A (1998) The Present Situation of School Libraries in Jordan. Risalat Al-Maktaba 33(3, 4): 18.

Al Maneh A (2007) Hiring School Library at the Elementary Level in Support of the Curriculum. Retrieved from http://b7oth.com/?p=1300. 
Al Momani G, Abu Ajamiyeh Y, Subaihi M, Al Soufi A (1998) Theoretical Framework of the Present Situation of School Libraries in Jordan. Risalat AlMaktaba [Library Message] 33(3, 4): 41.

Al Momani G, Abu Ajamiyeh Y, Subaihi M, Al Soufi A (1998) Theoretical Framework of the Present Situation of School Libraries in Jordan. Risalat AlMaktaba 33(3, 4), 42.

Al Momani G, Al Soufi A, Abu Juma A (1998) The Present Situation of School Libraries in Jordan . Risalat Al-Maktaba [Library Message] 33(3, 4): 20-22.

Al Momani G, Al Soufi A, Abu Juma A (1998) The Present Situation of School Libraries in Jordan. Risalat Al-Maktaba 33(3, 4), 65.

Al Shafi AH (1993) Child Library, 252. Cairo: Dar Alketab Almasrea.

Al Shimi HA (1986) The Role of Educational Values for School Libraries: Applied study, 21. Riyadh: Dar Almarekh.

Al Tartouri M (2007) Piaget Child's Cognitive Development. Retrieved from http://bit.ly/1RIOR3S. [Accessed April 2015].

Central Committee of UNRWA (2011) The Role of School Library in Teaching and Learning Processes: the UNRWA schools in Jordan's experience, the preparation of the Central Committee of school libraries. Risalat Al-Maktaba 46(2): 41-70.

Closing Committee (1992) Recommendation of 2nd Conference of Librarians in Jordan (6-8 October). Risalat Al-Maktaba 27(1).

Eduwave (2015). Jordan E-learning System. Retrieved from http://bit.ly/1IIWHqz.

El Sheikh A (1989) The Reality of Secondary School Libraries in Jordan. Jordan Library Association, 117.

Elayyan R, Al Najdawi A (1999) Introduction to Library and Information Science. Amman: Dar Alfecer for Printing and Publishing.

Guendel Y (1995) Al-Akhras Biography. Risalat Al-Maktaba [Library Message] 30(3), 65-76.

Lance KC, Schwarz B (2012) How Pennsylvania School Libraries Pay Off: Investments in Student Achievement and Academic Standards. Retrieved from http://bit.ly/1QitXr1.

Lance Keith C, Loertscher DV (2005) Powering Achievement: School Library Media Programs Make a Difference: The Evidence. (3rd ed). Salt Lake City, UT, California: Hi Willow Research \& Pub.

Ministry of Education (2012) Saudi Arabia: Ministry is moving to set up computer laboratories and mobile libraries to serve areas. Retrieved from http://bit.ly/ 1Nm3piL. [Accessed April2015].

Ministry of Education (2013) Statistical Report of. Retrieved from http://bit.ly/ 1IISX8s. [Accessed January 2015].

Ministry of Education (2010) The general framework of Investigation and calendar public, private and academic outcomes for all detective. Retrieved from http://bit.ly/1Q62Fo6. [Accessed February 2015]

Shawabkeh YA (2011) How can the Information Specialist Hiring School Library in Serving the Courses and Teaching and Learning Processes. Risalat Al-Maktaba 46(2).

Study Plans for the Academic Year 2006/2007. Faculty of Arts, Department of Library Science, Al-Hussein Bin Talal University (AHU).

Study Plans for the Academic Year 2004/2005. Faculty of Education, Al-Hussein Bin Talal University (AHU).

Symposium of the Present Situation of School Libraries in Jordan: Organizing by Ministry of Education Cooperation with ALECSO. 1998. Risalat Al-Maktaba 33(3, 4): 10-11. 
School Libraries and its Role in Education and Learning Processes: Researches of School Libraries Meeting (2011) Risalat Al-Maktaba 46(2, 4): 11-13.

The Spread and Use of Information and Communication Technologies in the Hashemite Kingdom of Jordan Jordanian Schools: Survey Study. 2012. Retrieved from http://bit.ly/1Nfvdr6. [Accessed April 2015].

Tougan A (1995) School Library and its Role in Supporting and Promoting the Habit of Reading and Enhance the Curriculum. Risalat Al-Maktaba 30(3): 4-30. 
